\title{
Transcriptomics Analysis of Nrf2 Regulators in Cancer Resistant and Long-Lived Naked Mole-Rats
}

\author{
Perinur Bozaykut Eker ${ }^{1}$ iD
}

${ }^{1}$ Acıbadem Mehmet Ali Aydınlar Üniversitesi, Fen Edebiyat Fakültesi, Moleküler Biyoloji ve Genetik Anabilim Dalı, İstanbul, Türkiye

Perinur BOZAYKUT EKER, Dr. Öğr. Üyesi

Correspondence: Perinur Bozaykut Eker Acıbadem Mehmet Ali Aydınlar Üniversitesi, Fen Edebiyat Fakültesi, Moleküler Biyoloji ve Genetik Anabilim Dall, İstanbul, Türkiye Phone: +905558232919

E-mail: perinur.eker@acibadem.edu.tr

\section{ABSTRACT}

Purpose: Naked mole-rats (NMR, Heterocephalus glaber) have extreme resistance to cancer although they are known as the longest-living rodent with their 30 -year maximum lifespan. Therefore, NMRs have rapidly emerged as a natural model for biomedical research. Studies have shown that NMRs can better tolerate stress due to mechanisms, such as upregulation of the Nrf2 pathway. Another mechanism proposed to contribute to their protection from stress involves stem cells. Therefore, in this study, we aimed to identify the regulation of Nrf2 signaling in NMR fibroblasts and induced pluripotent stem cells (iPSCS).

Methods: The transcriptomics data of NMR and laboratory mice (Mus musculus) were used in the study. Particularly, the genes that are accepted as Nrf2 activators (Dpp3, Sqstm1, Palb2, Amer1, Mapk14, Trp53) and inhibitors (Keap1, Siah1, Btrc) were comparatively analyzed in fibroblasts and iPSCs of both species.

Results: Our data demonstrated differentially expressed gene expressions between different cell types. Among target Nrf2 activators, Palb2 RNA expression was found to be increased significantly $(p<0.0001)$ in NMR fibroblasts when compared to mouse fibroblasts. In addition, the expression of Palb2 was even more increased in NMR iPSCs when compared to NMR fibroblasts $(p<0.0001)$.

Conclusion: It was shown, for the first time, Palb2 could be partially responsible for the activation of Nrf2 pathway. These results contribute to literature on the stress resistance of the NMRs and its relationship with their superior features of aging and cancer.

Keywords: Transcriptomics, stress resistance, naked mole-rat, Nrf2 signaling, aging, cancer

Kansere ve yaşlanmaya karşı üstün dirençli farelerde Nrf2 yolağını düzenleyen faktörlerin transkriptomik düzeyde analizi

ÖZET

Amaç: Çıplak Kör Fareler (ÇKF), 30 yılı aşkın sıra dışı uzun yaşam sürelerine sahip olmaları ve bu uzun yaşamları boyunca kanser gelişimi göstermemeleri ile biyomedikal arastırmalarda kullanılmaktadır. Yapılan calıșmalar, CKF'lerin üstün bir stres direncine sahip olduğunu ve temel bir oksidatif stres mekanizması olan Nükleer faktör-eritroit 2 ilişkili faktör (Nrf2) sinyal yolağının önemli bir rolü olduğunu göstermektedir. CKF'leri stresten koruyan başka bir mekanizmanın ise sağlık alanında sıklıkla kullanılan kök hücreler olduğu düsünülmektedir. Bu sebeplerden dolayı yapılan çalısmanın amacı, kör farelerin fibroblast ve indüklenmiş pluripotent kök hücrelerinde Nrf2 ekspresyonunu düzenleyen faktörlerin tayin edilmesidir.

Yöntem: CKF'ler ve laboratuvar farelerinin (Mus musculus) RNA sekanslama metodu ile elde edilen transkriptom verileri kıyaslamalı olarak analiz edildi. Bu 2 türe ait fibroblast ve indüklenmiş pluripotent kök hücrelerine ait veriler spesifik olarak Nrf2 aktivatörleri (Dpp3, Sqstm1, Palb2, Amer1, Mapk14, Trp53) ve inhibitorleri (Keap1, Siah1, Btrc) olarak kabul edilen genler açısından incelendi.

Bulgular: Elde edilen bulgular, CFK hücrelerinde Nrf2 aktivatör ve inhibitör adayları arasındaki RNA ekspresyonları değişimlerini gösterdi. Fare fibroblast hücrelerine kıyaslandığında, ÇKF fibroblast hücrelerinde Nrf2 aktivatörü olarak kabul edilen Palb2 RNA ekspresyonunda önemli düzeyde artış $(p<0.0001)$ olduğu ve ÇKF iPSC hücrelerinde Palb2 ekspresyonunun daha da fazla arttığı $(p<0.0001)$ görüldü.

Sonuç: Elde edilen bulgular, ÇKF'lerde Nrf2 yolağının aktivasyonunda Palb2'nin rolü olabileceğini göstermektedir. Bu veriler, yaşlanma ve kansere karşı sıra dışı özelliği olan bu türlerin stres direnci ile ilgili mekanizmalarının aydınlatılmasına katkı sağlamaktadır.

Anahtar Kelimeler: Transkriptomiks, çıplak kör fare, Nrf2, yaşlanma, kanser 
$\mathbf{N}$ aked mole-rats (NMR, Heterocephalus glaber), the longest-lived rodent known, have rapidly emerged as a natural model of aging based upon its more than 30-year maximum lifespan and positive healthspan. NMR lives 8 times longer than similar-sized mouse and sustains good health for most of its life, which would be equivalent to 80-year-old humans exhibiting a 30-year-old 'biological age'. NMRs demonstrate negligible senescence, no age-related increase in mortality, and high fecundity until death (1). Most importantly, NMRs do not exhibit age-related cancer pathologies different from mice. This information points the importance of molecular mechanisms related to the superior properties of NMRs (2).

Several studies have already revealed molecular mechanisms of NMRs. As such, NMRs exhibit minimal or no agerelated differences in biochemical processes and protein homeostasis, in contrast to laboratory mice (Mus musculus) (3). A study, which was conducted on NMR genome and transcriptome sequences, has shown that there are significant differences between gene expressions associated with oxidative stress (4). This study revealed that the activity of peroxiredoxins and glutathione peroxidase 1 (GPX 1) which are closely related to oxidative stress are lower in NMRs. Given the fact that NMRs have superior resistance to aging and cancer, the low expression levels of these antioxidant enzymes are surprising since oxidative stress has significant role in the development of cancer, neurodegenerative and cardiovascular diseases (5).

It is considered that different proteins and cellular defense mechanisms play a role under these properties (6). Of the$\mathrm{se}$, it has been suggested that the activation of the nuclear factor-erythrocyte 2 related factor (Nrf2) antioxidant pathway is effective in the cellular defense mechanism of NMRs. When activated, Nrf2 translocates into the nucleus and increases the transcription of antioxidant proteins, subunits of proteasome, and autophagy-related genes. As a result, with the Nrf2 signaling pathway activation, misfolding and aggregation of proteins due to oxidative stress is prevented (6-8). Besides, the Nrf2 signaling pathway has also been associated with various human diseases such as cancer (9), atherosclerosis (10), and neurodegeneration (11). A study demonstrated that gene expressions of Nrf2 and its downstream antioxidant enzymes, were higher in NMR fibroblasts when compared to mouse fibroblasts under normal stress conditions (1). Previous studies have also revealed that the Nrf2 pathway may be responsible for longevity and stress resistance in NMRs; however, how Nrf2 pathway is regulated in NMRs is not well-known.
Induced pluripotent stem cells (IPSCs) are promising biological materials, particularly for regenerative medicine (12), and it is proposed that the stem cell characteristics could contribute to the superior biology of NMRs $(2,13)$. Regarding this information, the aim of this study is to examine the molecular mechanisms underlying the stress resistance of NMR at the transcriptome level in IPSCs, in addition to fibroblasts. Therefore, it is aimed to determine the regulators of Nrf2 pathway in NMRs, as they show a superior stress resistance throughout their lives in addition to having a longer lifespan and cancer-resistance.

\section{Method}

RNA Sequencing and analysis of raw data

The RNA sequencing analysis of fibroblasts and IPSCs of laboratory mice $(n=4)$ and NMRs $(n=6)$ were performed in the previous study (2) and raw data (SRP116326) were reanalyzed in terms of Nrf2 signaling pathway activators and inhibitors for this study. Briefly, embryonic fibroblast cells and IPSC were obtained as follows; Mouse embryos were collected from the fetus on day 13 and rinsed with PBS and lysed with $0.25 \%$ trypsin-EDTA solution. Trypsin was inactivated by DMEM (Dulbecco's Modified Eagle's medium), containing 20\% FBS (Fetal bovine serum). The obtained mouse embryonic fibroblast cells were cultured in DMEM containing 10\% FBS, penicillin/streptomycin $(10,000 \mathrm{U} / \mathrm{ml}), 1 \times$ non-essential amino acid, $0.1 \mathrm{mM}$ $\beta$-mercaptoethanol at $37^{\circ} \mathrm{C}$ and $5 \% \mathrm{CO}$. Following the isolation of NMR embryonic cells in the same way, they were cultured in hypoxic $(3 \% \mathrm{O} 2)$ and hypothermic $\left(32^{\circ} \mathrm{C}\right)$ conditions containing $5 \% \mathrm{CO} 2$, which meet the optimal oxygen and temperature conditions for NMR cells (13). Cells were, then, reprogrammed into IPSCs as follows; Fibroblast cells were transduced with lentiviruses carrying polycistronic mouse OSKM and FUW-M2rtTA vectors. Viral supernatants were added to cell media two times for 24 hours. After 3 days of incubation, they were seeded on mitomycin C inactivated cells and N2B27 + 2i reprogramming medium containing $2 \mu \mathrm{g} / \mathrm{ml}$ doxycycline was added to the cells. The culture media was renewed with 24-hour intervals. Embryonic stem cell-like colonies were incubated in N2B27 + 3i medium. Cells were cultured for 6 days and doxycycline was withdrawn (13).

The protocol for RNA sequencing analysis of obtained cells is as follows; Total RNA was isolated using RNA Mini kit (Qiagen, Germany). The amount and purity of RNA were quantified using a Qubit fluorometer (ThermoFisher Scientific, America). The library quantification was sequenced in 2 directions using TruSeq Sample Prep kit v2 
(Illumina, USA) with 101 base-pairs in all directions (2). For the analysis of RNA expression Mus musculus (GRCm38) and Heterocephalus glaber (hetGla2) reference genomes were used from the NCBI database (https://www.ncbi.nlm. nih.gov/genome/). For differential gene expression analysis, the data were first analyzed with the FastQC quality control tool, and the reference genomes of the raw data were mapped to the transcriptome, which were generated using the software of STAR-ultra-fast RNA-Seq aligner. The files, which had been obtained after mapping, were quantified via the software of Salmon, and converted into transcript numbers that were expressed in each sample. Genes, that are accepted as activators and inhibitors of $\mathrm{Nrf2}$, were retrieved from these data. Differential gene expression analysis was performed through the DESeq2 library running on the $\mathrm{R}$ analytics platform, and differentially expressed genes that were statistically significant among the compared groups were identified with their upregulated/downregulated status and their p-values.

\section{Statistical analysis}

Statistical analysis between groups was conducted using the software of GraphPad Prism 7.0. One-way analysis of variance (ANOVA) and Tukey's test were used to determine statistical difference and $p$ values. In the same species analysis, the groups were compared as mouse fibroblast vs mouse iPSC and NMR fibroblast vs NMR iPSC. In across the species analysis, the groups were compared as mouse fibroblast vs NMR fibroblast and mouse iPSC vs NMR iPSC. The results were considered statistically significant at $p<0.05$.

\section{Results}

In this study, RNA expressions of Nrf2 pathway regulators were investigated in fibroblasts and IPSCs in comparison to mice. Studies on other species have identified Dipeptidyl Peptidase 3 (Dpp3), Sequestosome 1 (SQSTM1), Partner and Localizer of BRCA2 (Palb2), APC Membrane Recruitment Protein 1 (Amer1 or WTX), Mitogen-Activated Protein Kinase 14 (Mapk14) and Tumor Protein P53 (Trp53 or p53) as Nrf2 activators (14-17). On the other hand, Kelch-like ECH-Associated Protein 1 (Keap1), E3 Ubiquitin Protein Ligase 1 (Siah1), and BetaTransducin Repeat Containing E3 Ubiquitin Protein Ligase (BTRC) have been identified as Nrf2 inhibitors $(15,18)$. However, it is not known which genes are responsible for Nrf2 pathway activation in NMRs and it was investigated at the transcriptome level in the present study.
Our RNA expression findings on Nrf2 activators demonstrated that Dpp3 was significantly increased in mouse IPSCs compared to mouse fibroblasts (Fig. 1a). No significant change was found between groups in Amer1 RNA expressions (Fig. 1b). However, it was observed that Mapk14 RNA expression decreased in NMR fibroblasts compared to mouse fibroblasts (Fig. 1c).
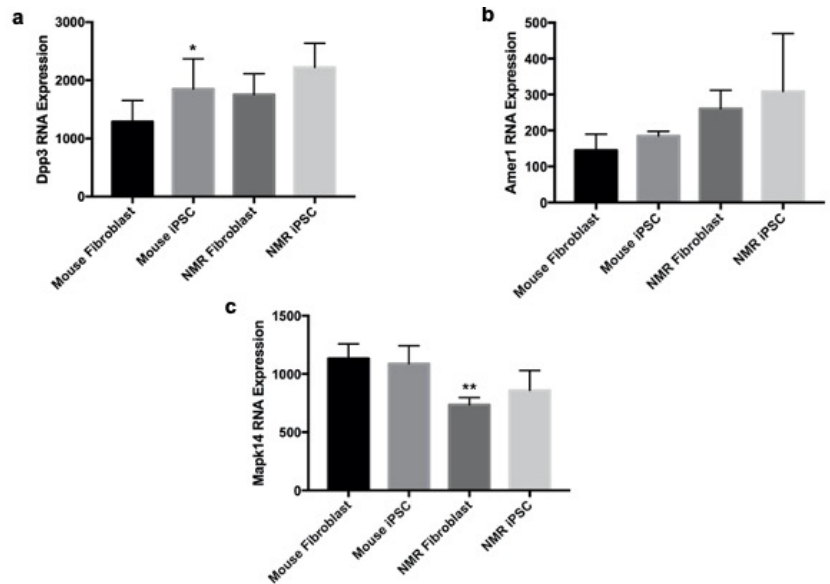

Fig. 1. RNA expression levels of various Nrf2 activators obtained from RNA-Sequencing analysis. a) Dpp3 RNA expression, ${ }^{*} p<0.05$ vs mouse fibroblast. b) Amer1 RNA expression, no significant change. $c$ ) Mapk14 RNA expression, ${ }^{* *} \mathrm{p}<0.005$ vs mouse fibroblast.

Palb2 RNA expression was significantly higher in iPSCs compared to fibroblasts of both species, while the expression was found to be higher in NMR fibroblasts compared to mouse fibroblasts (Fig. 2a). Palb2 RNA expression in NMR iPSCs was also significantly increased when compared to mouse iPSCs (Fig. 2a) as well. On the other hand, it was determined that Sqstm1 RNA expressions were decreased in iPSCs compared to fibroblasts in both species (Fig. 2b). Besides, there was no significant change in Trp53 RNA expressions (Fig. 2c).

The results on Nrf2 inhibitors showed that the expression of Btrc was increased in NMR fibroblasts compared to mouse fibroblasts (Fig. 3a), and Siah1 expression was expressed at high levels in NMR iPSCs (Fig. 3c). However, no significant change was observed in Keap1 RNA expressions (Fig. 3b).

These results indicate that RNA expression of Palb2, which is known as an Nrf2 activator, could be effective on the activation of Nrf2 pathway in NMRs, as it increases significantly in both NMR fibroblast and NMR iPSCs when compared to mice. 


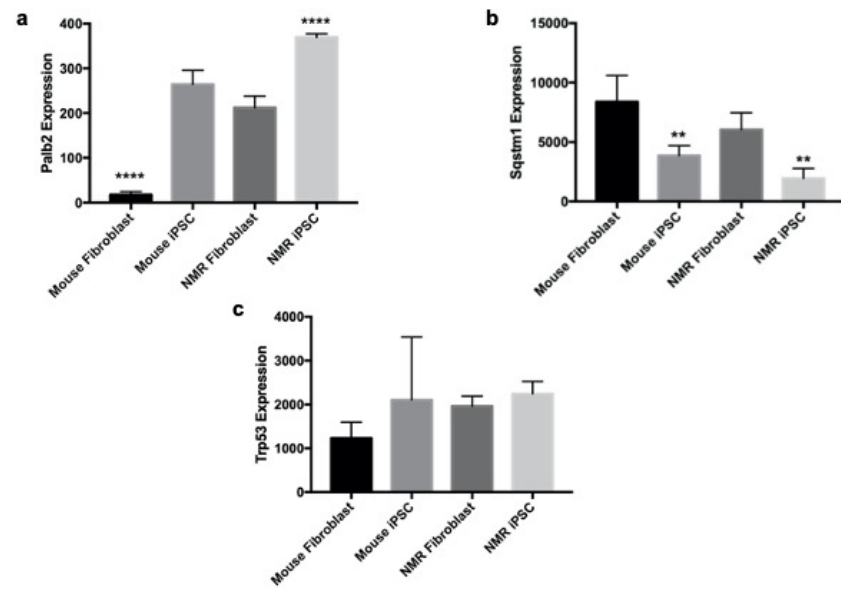

Fig. 2. RNA expression levels of various Nrf2 activators obtained from RNA-Sequencing analysis. a) Palb2 RNA expression, ${ }^{* * * *} p<0.0001$ mouse fibroblast vs mouse iPSC, mouse fibroblast vs NMR fibroblast, NMR fibroblast vs NMR iPSC and mouse iPSC vs NMR iPSC. b) Sqstm1 RNA expression, ${ }^{* *} p<0.005$ mouse fibroblast vs mouse iPSC, NMR fibroblast vs NMR iPSC. c) Trp53 RNA expression, no significant change.

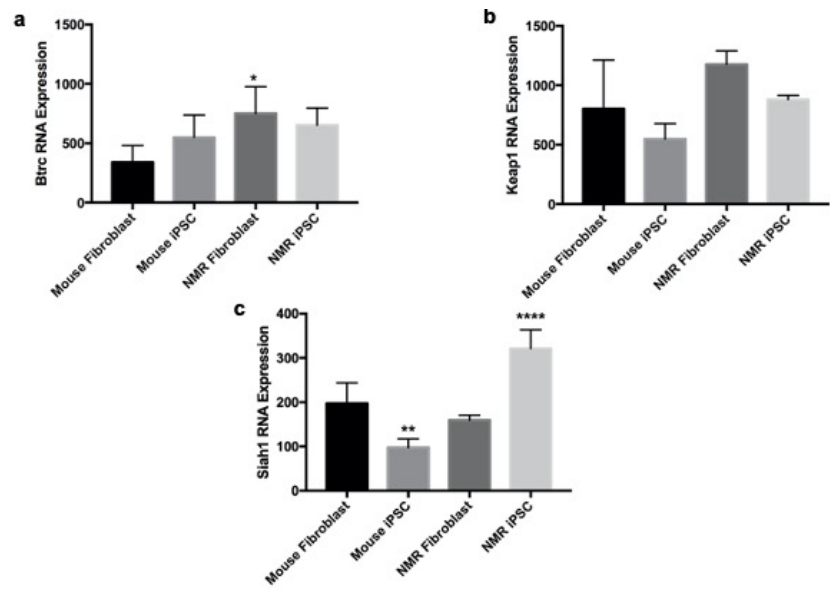

Fig. 3. RNA expression levels of Nrf2 inhibitors obtained from RNASequencing analysis. a) Btrc RNA expression, ${ }^{*} p<0.05$ vs mouse fibroblast. b) Keap1 RNA expression, no significant change. c) Siah1 RNA expression, ${ }^{* * * *} p<0.0001$ vs NMR fibroblast and mouse iPSC, ${ }^{* *} \mathrm{p}<0.005$ vs mouse fibroblast.

\section{Discussion}

Oxidative stress mainly results from an imbalance between reactive oxygen species and antioxidant defense mechanisms of the cell. Oxidative stress has been closely associated with aging and aging-associated diseases, therefore, resistance to oxidative stress is indicated to lead extension of healthspan and lifespan (1). NMRs are frequently used in biomedical research as their metabolic rates are very slow and their protein structures are not affected by oxidative stress throughout aging process (6). It is considered that these superior characteristics might be associated with various molecular mechanisms and that, in particular, activation of the Nrf2 antioxidant pathway is proposed to be responsible for their stress resistance (6).

Nrf2 is a transcription factor, which is expressed in all tissues and activated under stress conditions (21). Under normal conditions, Nrf2 is in the cytosol and in its inactive form. However, under stress conditions, it translocates to the nucleus, activating the transcription of numerous crucial genes (22). These molecules include redox regulators such as glutathione-S-transferase (GST), NAD (P) H: quinone oxidoreductase (NQO1), molecular chaperones, and proteasome subunits $(1,6)$. A previous study has shown that Nrf2 expression is three times higher in NMR fibroblasts compared to mouse fibroblasts indicating the essential role of Nrf2 pathway for the extraordinary resistance of NMRs against aging-associated cancer, cardiovascular diseases, and neurodegenerative diseases (21). However, detailed analysis of the factors regulating Nrf2 expression in NMR's fibroblasts and iPSCs has not been performed yet. Hence, activators and inhibitors associated with the Nrf2 antioxidant pathway were investigated at the level of RNA expression in the present study. For this aim, Dpp3, Sqstm1, Palb2, Amer1, Mapk14, Trp53 as Nrf2 activators and Keap1, Siah1, Btrc proteins as Nrf2 inhibitors, were analyzed in NMR cells. To elucidate Nrf2 pathway activation in NMRs, the obtained results were examined in terms of the increase in RNA expression level of activator genes or the decrease in RNA expression level of inhibitor genes.

The studies that have been performed so far show that the NMR has been mainly investigated by comparing with mice (21-23), thus, in our study, NMR RNA expressions were analyzed comparatively with mice. Our results demonstrated that among Nrf2 activators, Palb2 was increased significantly in NMR fibroblasts and iPSCs compared to mice. The increase of Palb2 in both fibroblasts and iPSCs in NMRs indicates that Palb2 could play a role in the activation of Nrf2 pathway in NMRs. Besides, Palb2 is a protein that binds to BRCA genes and regulates the functions of BRCA factors which are closely associated with breast cancer. Studies have shown that the Palb2 mutation is mainly responsible for genetically derived breast cancer (24). Palb2 is known to bind Nrf2 inhibitors so the possible role of Palb2 in the Nrf2 pathway could be indirect activation of Nrf2 that results in the transcription of antioxidant genes (25). 
Nrf2 can also be activated by phosphorylation with kinase proteins such as Mapk14 (16). However, our findings show that Mapk14 RNA expression decreases in NMR fibroblasts. On the other hand, as this decrease is not as high as the increase observed in Palb2, it is considered that its impact on Nrf2 pathway activation might be minor. Moreover, it is hypothesized that the Nrf2 pathway is regulated by the combinational effect of various regulator proteins rather than being under the control of a single protein.

Based on the findings gained from the study; it is observed that the RNA expressions of activators and inhibitors associated with the Nrf2 pathway are not expressed at the same levels between different species and cells. Although Palb2 expression were analyzed for the first time in NMR fibroblasts and iPSCs, our findings indicate that Palb2 expression could have a role in the regulation of $\mathrm{Nrf2} \mathrm{ac-}$ tivation consistent within the previous studies. However, further studies are required to clarify the direct effect of Palb2 in Nrf2-signaling for the extra-ordinary properties of NMRs.

\section{Acknowledgments}

This study is supported by Scientific and Technological Council of TURKEY (1059B191501668). I would like to thank Prof. Vadim Gladyshev and Dr. Sang Goo Lee for their support in this study.

\section{References}

1. Lewis KT, Mele J, Hornsby PJ, Buffenstein R. Stress Resistance in the Naked Mole-Rat:The Bare Essentials - A Mini-Review. Gerontology 2012; 58: 453-462.

2. Lee SG, Mikhalchenko AE, Yim SH, et al. Naked mole rat induced pluripotent stem cells and their contribution to interspecific chimera. Stem Cell Rep 2017; 9: 1706-1720.

3. Buffenstein R. Negligible senescence in the longest living rodent, the naked mole-rat: insights from a successfully aging species. J Comp Physiol B 2008; 178: 439-445.

4. Fang X, Wang J, Gladyshev VN et al. Adaptations to a Subterranean Environment and Longevity Revealed by the Analysis of Mole Rat Genomes. Cell Reports 2014; 8: 1354-1364.

5. Andziak B, O'Connor TP, Qi W, et al. High oxidative damage levels in the longest-living rodent, the naked mole-rat. Aging Cell 2006; 5: 463-471.

6. Rodriguez KA, Wywial E, Perez VI, et al. Walking the Oxidative Stress Tightrope: A Perspective from the Naked Mole-Rat, the LongestLiving Rodent. Curr Pharm Des 2011; 17(22): 2290-2307.

7. Waal EM, Liang $\mathrm{H}$, Pierce $\mathrm{A}$, et al. Elevated protein carbonylation and oxidative stress do not affect protein structure and function in the long- living naked mole-rat: a proteomic approach. Biochemical and Biophysical Research Communications 2013; 4: 815-819.

8. Lewis KN, Mele J, Hayes JD, et al. Nrf2, a guardian of healthspan and gatekeeper of species longevity. Integrative \& Comparative Biology 2010; 5: 829-843.
9. Hayes JD, McMahon M. NRF2 and KEAP1 mutations: permanent activation of an adaptive response in cancer. Trends Biochem Sci 2009; 34: 176-188.

10. Bozaykut P, Karademir B, Yazgan B, et al. Effects of vitamin E on peroxisome proliferator-activated receptor $\gamma$ and nuclear factorerythroid 2-related factor 2 in hypercholesterolemia induced atherosclerosis. Free Radical Biology\&Medicine 2014; 70: 174-181.

11. Kraft $A D$, Johnson $D A$, Johnson JA. Nuclear factor E2-related factor 2-dependent antioxidant response element activation by tert butylhydroquinone and sulforaphane occurring preferentially in astrocytes conditions neurons against oxidative insult. J Neurosci 2004; 24: 1101-1112.

12. Lemey C, Milhavet O, Lemaitre JM. iPSCs as a major opportunity to understand and cure age-related diseases. Biogerontology 2015; 16: 399-410.

13. Lee SG, Mikhalchenko AE, Yim SH, et al. A naked mole rat iPSC line expressing drug-inducible mouse pluripotency factors developed from embryonic fibroblasts. Stem Cell Reports, 2018; 197-200.

14. Komatsu M, Kurokawa $\mathrm{H}$, Waguri $\mathrm{S}$, et al. The selective autophagy substrate p62 activates the stress responsive transcription factor Nrf2 through inactivation of Keap1. Nat. Cell Biol 2010; 12, 213-223.

15. Camp ND, James RG, Dawson DW, et al. Wilms tumor gene on $X$ chromosome (WTX) inhibits degradation of NRF2 protein through competitive binding to KEAP1 protein. J Biol Chem 2012; 24;287(9):6539-50.

16. Mitra A, Ray A, Datta R, et al. "Cardioprotective role of P38 MAPK during myocardial infarction via parallel activation of a-crystallin B and Nrf2". Journal of Cellular Physiology, 2014; 229 (9): 1272-82.

17. Tonelli C, Chio IIC, Tuveson DA. Transcriptional Regulation by Nrf2. Antioxid. Redox Signal 2018;29:1727-1745.

18. Hayes JD, Dinkova-Kostova AT. The Nrf2 regulatory network provides an interface between redox and intermediary metabolism. Trends in biochemical sciences 2014; 39 (4): 99-218.

19. Harper JM, Salmon AB, Leiser SF, et al. Skin-derived fibroblasts from long- lived species are resistant to some, but not all, lethal stresses and to the mitochondrial inhibitor rotenone. Aging Cell 2007; 6: $1-13$.

20. Salmon AB, Akha AAS, Buffenstein R, et al. Fibroblasts from naked mole-rats are resistant to multiple forms of cell injury, but sensitive to peroxide, ultraviolet light, and endoplasmic reticulum stress. Gerontol A Biol Sci Med Sci 2008; 63: 232-241.

21. Lewis KN, Wason E, Edrey $\mathrm{YH}$, et al. Regulation of Nrf2 signaling and longevity in naturally longed-lived rodents. Proc Natl Acad Sci U S A 2015; (12): 3722-3727.

22. Rodriguez $\mathrm{KA}$, Edrey $\mathrm{YH}$, Osmulski $\mathrm{P}$, et al. Altered composition of liver proteasome assemblies contributes to enhanced proteasome activity in the exceptionally long-lived naked mole-rat. PLoS ONE 2012; 7(5):e3589.

23. Bozaykut P. Cellular stress responses of long-lived and cancerresistant naked mole-rats. Turkish Journal of Biochemistry 2021 46:2. DOI: 10.1515/tjb-2020-0480.

24. Rahman N, Seal $S$, Thompson $D$, et al. PALB2, which encodes a BRCA2-interacting protein, is a breast cancer susceptibility gene. Nat. Genet 2007; 39: 165- 167.

25. Ma J, Cai $\mathrm{H}, \mathrm{Wu}$ T, et al. PALB2 interacts with KEAP1 to promote NRF2 nuclear accumulation and function. Mol. Cell. Biol 2012; 32:1506-1517. 